\title{
Learning opportunities of urban space semiotics
}

\author{
Lyudmila Silchenkova ${ }^{1 *}$, Sergey Likhachev ${ }^{1}$, Natalya Desyaeva ${ }^{1}$, Tatyana Likhacheva ${ }^{1}$, and \\ Natalia Sheveleva ${ }^{2}$ \\ ${ }^{1}$ Moscow City University, Institute of Pedagogy and Psychology of Education, Department of \\ Training Methods, Moscow, Russia \\ ${ }^{2}$ Moscow City University, Institute of Continuing Education, Department of Pedagogical \\ Technologies of Continuing Education, Moscow, Russia
}

\begin{abstract}
The article deals with the study of the semiotic opportunities of the urban space as a learning tool. The authors analyze the literature on urban research and point to the significant interest of the education system in various manifestations of urban life: architectural, design, environmental, adaptational, etc. The notion of "city" in numerous studies usually means an environment full of different natural objects and structures. The latter should include houses, sculptural and architectural monuments, specially organized urban space, for example, the city center and its peripheral area marked with certain signs. Researchers insist that a city is a complex semiotic space in which a citizen lives and navigates. Various types of signs are actively involved in the organization of urban life (Ch. Peirce). Thus, iconic signs make it easy to navigate the city without resorting to decoding symbolic signs, i.e. without reading the signs and names of, for example, stores: a boot hanging next to the signboard allows one to determine that the citizen is in front of a shoe store. A child navigates such signs easily, however, participating in orienting activities on par with adults. The purpose of this article is to consider the city learning opportunities for helping young children to form the semiotic activity which is included in various types of educational activities. The novelty of the research presented in the article is confirmed by the lack of scientific publications that directly consider the educational opportunities of urban space semiotics. The main research method is the code reconstruction method. The figure of a child plays an important role in the study. The child acts as the central subject of perception of the citytextbook. Following the idea of the most prominent researchers of semiotics, the authors regard the city as a text for a child to read. The analytical part of the article is based on recording children's impressions of the urban text.
\end{abstract}

Keywords: education, city, text, sign.

\footnotetext{
${ }^{*}$ Corresponding author: lui-sil@yandex.ru
} 


\section{Introduction}

The urban environment is studied by many sciences: philosophy, cultural studies, art history, urban studies, and others. In connection with education, the city is considered in terms of its reflection in virtual reality [1], architecture [2], student participation in smart city projects [3], efforts to preserve a clean environment [4], socialization of visiting students in the city [5], accessibility of the city for low-mobility students [6], and organization of the urban environment for students [7]. All this testifies to the relevance of this study. We proceed from the idea that the process of exploring the symbolic space of the city predicts the formation of a child's semiotic activity.

Based on research in related sciences - linguistics, semiotics, and pedagogy, one can define a city as a complex semiotic construct where a citizen must navigate, obtaining experiences and realizing the complex connections between its structural parts. Thus, the city center always has a symbolic meaning, according to Roland Barthes, "The center of our cities is always full: a marked sight, it is here that the values of civilization are gathered and condensed: spirituality (churches), power (offices), money (banks), merchandize (department stores), language (agoras: cafes and promenades)" [8:44]. The above must be taken literally, i.e. each building is a sign as the building has an ideal content: a church means a cult, a school means to study, a clinic means medicine. "The City is an ideogram: the Text continues" [8:45]. Provided that each architectural structure is a sign, the functional totality of signs (the city) is a text, the perception of which is reading.

The subject of the study, some of the results of which are presented in this article, are the learning opportunities of the urban space semiotics, which, based on philosophical, cultural, sociological, and philological studies can be defined as a complex semiotic construct [9].

Any knowledge, especially linguistic, is absorbed well if it is required and applicable in a situation. By reading a signboard, a child gains an experience of action, in which the ability to decipher (decode) signs in life is realized: the child distinguishes a residential building from neighboring schools and clinics. Perceiving iconic signs as additional means of marking trade establishments correctly identifies them. In other words, one's degree of socialization largely depends on what sign systems one has become acquainted with, what strategies for processing written speech - from letters to reading texts - one mastered, how one knows how to consider the context of reading [10]. Meanwhile, the city is a field of the interpenetration of many sign systems, from which the symbolism of urban space is generally composed. Symbols of urban space have been forming for a long time as a result of realizing the relationship between reality and human consciousness [11]. The symbolism of urban space can be represented as a discourse of certain concepts, connections, and relationships, as a human-inhabited space that contains a system of symbolic messages fixed within through signs of different textures [12] and nature and thus included in the urban environment.

Every child can learn to "read" the urban text on an intuitive level as the urban space has intersubjective significance. Indeed, the symbols of the city organize the collective life of the city. This applies to posters, advertisements, and signs, in which, along with symbolic signs, iconic ones are widely used, which greatly facilitates their deciphering. The city, unlike the countryside, cannot do without road signs. At the green light of the traffic light, some people start moving along the pedestrian zebra crossing, while people in cars stop. Gradually, the process of urban text recognition is transferred from the sphere of intuition to the sphere of conscious, detailed, and error-free activity which can be qualified as the education of a young citizen through urban space, organized according to the laws of sign systems. At the same time, the text of the city is already penetrating the works of other cultural practices, in particular, in the cinema "subtitles are increasingly being written into 
the reality of the film, for example, on signs and billboards" [13:56]. By analogy, the idea emerges about the relevance of including the urban text in education.

The purpose of this article is to develop general approaches to using urban objects for teaching various sign systems to students. These systems include the alphabet, mathematical signs (numbers), signs of orientation in space, road signs, and architecture. Using the semiotic space of the city as a learning tool, one can, to a degree, contribute to the development of different competencies of young children.

The novelty of our research consists in the fact that the phenomenon of urban space as a complex semiotic text is for the first time considered from the perspective of its direct educational capabilities - as a means of forming a child's complex mental activity - the sign activity.

The hypothesis of the study is the assumption that the process of mastering the semiotic space of the city should be considered a factor in the formation of the child's sign activity, which is presented in various forms in many types of learning activity.

The city's onomasticon which is presented in foreign studies [14] and Russian publications [15] is particularly valuable for this research.

\section{Methods}

The method of this study is qualified as a code reconstruction method following T.V. Shmeleva [16]. The researcher proposed this term, examining the urban onomasticon in a communicative aspect, i.e. from an activity standpoint, thinking of an active "reader" (subject) of the urban space who navigates the space, organizing the reader's activities. When teaching sign activity to a child through urban onomasticon, adults (teachers, parents, educators) should naturally be guided by the patterns of urban nomination. Most often, such a linguistic device as metonymy acts in this function [17]. Linguists distinguish several metonymic codes, for example, spatial: the Moscow river and the city of Moscow, the Oryol river - the city of Oryol, and others.

In addition to the spatial code of the nomination in the urban text, one can see other codes, for example, the subject code: the name of the store by the type of items sold there: "The Loaf", "The Fashionable Silhouette", "The Boot". The same is true for catering establishments: "Fork \& Spoon", "The Plate". Moreover, the city as an environment familiar to schoolchildren will help to approach the understanding of cultural signs.

If one considers that the results of the sometimes lengthy process of nomination reflect the cultural codes of the people, its history and modernity, then it seems appropriate to build a certain model for the exploration of urban onomasticon: the exploration of iconic urban signs - the gradual exploration of symbolic signs based on iconic ones - a comparison of the iconic and symbolic sign - the choice of the most convenient means of orientation in the urban space. It should be noted that we assume that the choice can be not only in favor of symbolic, although the most accurate signs. If we use E. Sapir's figurative formula that language is a symbolic key to culture, then in the proper name of the urban onomasticon one can see a combination of extremely specific denotative meaning (which greatly facilitates the orientation of children in the urban text) with a wide layer of connotations that allow a child master creative thought models. We see that if one uses the city as teaching material, one can significantly increase learning motivation, including in the process of developing children's reading competencies but not exclusively. Such material can perform the following functions: teach to read, count, navigate the space, as well as safe behavior and knowledge of the environment. 


\section{Results and discussion}

As of yet, we have only indirect evidence that the urban "text" affects the formation of sign (semiotic) activity in young children from the beginning of its formation (i.e., preschool) to its meaningful development at primary school age because "the writing of the urban environment" [12] is very difficult to isolate from the modern educational space. The educational environment today is full of books, newspapers, magazines, and other printed objects, from which, on the one hand, it is quite easy to visually distinguish objects of writing in the urban environment, for example, advertising, posters, banners. On the other hand, it is difficult to measure their educational effect. However, the indirect, although not always regular, result of the influence of the written urban environment still manifests itself, sometimes in an unexpected form, which makes one think about the semiotic foundations of the formation of the subject results in education [18].

In the "writing of the urban environment" one can find the use of graphic means of both Russian and other, most commonly Latin, alphabets, which generates the following "educational" situations. Seeing the image of the letter " $H$ ", a preschooler finds its sound correspondence, "This is the letter [h], my mother has a Honda car". Naturally, in this case, the child relied on the written letters - Honda - and learned the functional meaning of the letter-sign, although the child had not yet mastered the writing systems of different languages. When answering the question "What letter is this?", a five-year-old boy asks, "And where is this letter? Where dad puts the car (parking) or in my name Roma?" It is easy to see that the above examples indicate the spontaneous nature of the appearance in young children of a functional (simultaneous) attitude to the signs of the alphabet, which, according to modern researchers, is a condition for the formation of a reading mechanism [18].

Along with the analysis of children's impressions of the urban text, one can cite another authoritative opinion on this matter. "I had time to start missing the city, and I liked the fact that it was possible to play with large texts written on the walls of houses at the speed of reading while a car was passing by them", - this is the description of the process of learning to read by Vyacheslav Vsevolodovich Ivanov who was deprived of school education due to illness, a researcher of Indo-European antiquities, academician of the Russian Academy of Sciences, member of the British Academy and the American Academy of Arts and Sciences, professor of the Moscow State University, the Russian State University for the Humanities, the University of California, and Stanford. We see that the great linguist began his journey to reading from communication with the city. Meanwhile, the city turned out to be a good textbook for the child [19].

\section{Conclusion}

In Russia, $74.4 \%$ of the population live in cities. In modern pedagogical publications, it is noted that young children's level of mastering the reading mechanism has significantly increased. In Moscow schools, along with classes studying in primary school for four years, there are classes in which students were transferred to three-year primary education because that some of the first-year classes are entirely composed of children who can read. Naturally, this became possible due to the changed educational environment, in which, we believe, the city played a significant part. However, we believe that urban learning opportunities are far from being fully explored and require further research. 


\section{References}

1. V. Hain, M. Ganobjak, Presence: Teleoperators and Virtual Environments, 26(4), 355365 (2018). https://doi.org/10.1162/PRES_a_00309

2. Z.W. Paszkowski, J.I. Gołebiewski, World Transactions on Engineering and Technology Education, 18(1), 51 (2020)

3. F. Kurniawan, S.M.S. Nugroho, M. Hariadi, World Transactions on Engineering and Technology Education, 17(1), 93-97 (2019)

4. K.D. Shelest, V.V. Ionov, L.Y. Tikhomirov, International Journal of Sustainability in Higher Education, 18(1), 39-49 (2017). https://doi.org/10.1108/IJSHE-05-2015-0085

5. T. Verulava, et al., Youth Voice Journal, 9 (2019)

6. E.A. Petrovicheva, et al., EurAsian Journal of BioSciences, 13(2), 1559-1564 (2019)

7. A.A. Alhusban, Y.N. Al-Betawi, S.A. Alhusban, Journal of Place Management and Development, 12(3), 408-448 (2019). https://doi.org/10.1108/JPMD-07-2019-0066

8. R. Barthes, L'Empire des signes [Empire of Signs] (Praksis, Izvestia Publishing House, Moscow, 2004)

9. S.S. Kasatkina, Vestnik Voronezhskogo gosudarstvennogo universiteta. Seriya: philosophiya, 1(23), 113-120 (2017)

10. T.V. Chernigovskaya, et al., Vzglyad kota Shredingera: registratsiya dvizhenii glaz v psikholingvisticheskikh issledovaniyakh [The Gaze of Schrödinger's Cat: Eye-tracking in Psycholinguistics] (Saint Petersburg State University Publishing House, Saint Petersburg, 2018)

11. A.A. Leontev, Deyatelnyi um (Deyatelnost, Znak, Lichnost) [Activity brain (Activity, sign, personality)] (Smysl, Moscow, 2001)

12. T.V. Shmeleva, Calligraphy of the city: Novgorod observations, in Proceedings of the III International Scientific Conference Visual Anthropology - 2019. City-University: Living Space and Visual Environment, Scientific and Educational Center Humanitarian urbanism of Yaroslav-the-Wise Novgorod State University, 28-30 August 2019, Veliky Novgorod, Russia (2020). https://doi.org/10.34680/visant-2020-216-226

13. S.V. Likhachev, Kommunikativnye issledovania, 3(17), 47-65 (2018). https://doi.org/10.25513/2413-6182.2018.3.47-65

14. C. Hough, D. Izdebska, The Oxford Handbook of Names and Naming (Oxford University Press, Oxford, 2016)

15. T.V. Shmeleva, Onomastikon rossiiskogo goroda [Onomasticon of the Russian city] (LAP Lambert Academic Publishing, Saarbrücken, 2014)

16. T.V. Shmeleva, Kommunikativnye issledovania, 6(1), 51-66 (2019). https://doi.org/10.25513/2413-6182.2019.6(1).51-66

17. T.V. Shmeleva, Uralskii filologicheskii vestnik. Series: Yazyk. Sistema. Lichnost: Lingvistika kreativa, 2, 219-227 (2020). https://doi.org/10.26170/ufv20-02-20

18. L.S. Silchenkova, Chelovek i yazyk v kommunikativnom prostranstve, 6(15), 218-226 (2015)

19. V.V. Ivanov, Ot bukvy i sloga k ieroglifu: sistemy pisma v prostranstve i vremeni (Yazyki slavyanskoi kultury, Moscow, 2013) 